\title{
Chemical Gradients and Chemotropism in Yeast
}

\author{
Robert A. Arkowitz \\ Institute of Developmental Biology and Cancer, Université de Nice - Sophia Antipolis - CNRS UMR6543, \\ Centre de Biochimie, Faculté des Sciences, Parc Valrose, 06108 Nice Cedex 2, FRANCE \\ Correspondence: arkowitz@unice.fr
}

Chemical gradients of peptide mating pheromones are necessary for directional growth, which is critical for yeast mating. These gradients are generated by cell-type specific secretion or export and specific degradation in receiving cells. Spatial information is sensed by dedicated seven-transmembrane G-protein coupled receptors and yeast cells are able to detect extremely small differences in ligand concentration across their $\sim 5-\mu \mathrm{m}$ cell surface. Here, I will discuss our current knowledge of how cells detect and respond to such shallow chemical gradients and in particular what is known about the proteins that are involved in directional growth and the establishment of the polarity axis during yeast mating.

C hemical gradients play critical roles in a large number of developmental processes. These gradients, which are precisely controlled at both temporal and spatial levels, provide an efficient means of encoding vectorial information. Although diverse fungi generate chemical pheromone gradients during mating, because of its genetic tractability, most studies on chemical gradients in yeast have focused on Saccharomyces cerevisiae. This review will focus on the role of chemical pheromone gradients during $S$. cerevisiae mating, as our knowledge of the molecular details of this chemotropic process is most advanced. This review is divided into four main sections: gradients, sensing and detection, cellular responses, and signal amplification. The second and third sections are further divided, with the second section addressing the roles of pheromone receptors and hetero-trimeric
G-proteins, as well the mechanisms involved in detection of small differences in ligand concentration across a yeast cell. The third section focuses on the different cellular responses during chemotropism, in addition to what is known about how a growth site and an axis of polarity are established in response to an external gradient.

\section{GRADIENTS}

Most fungi produce diffusible peptide mating pheromones and in general, there are two different peptide mating factors (reviewed in Caldwell et al. 1995) in each species. Given the dynamic nature of pheromone gradients, it is not surprising that they have not been directly measured. Rather, various methods have been used to generate such gradients artificially and to determine cellular responses over a range of

Editors: James Briscoe, Peter Lawrence, and Jean-Paul Vincent

Additional Perspectives on Generation and Interpretation of Morphogen Gradients available at www.cshperspectives.org

Copyright (C) 2009 Cold Spring Harbor Laboratory Press; all rights reserved; doi: 10.1101/cshperspect.a001958

Cite this article as Cold Spring Harb Perspect Biol 2009;1:a001958 


\section{R.A. Arkowitz}

chemical gradient concentrations and slopes. During $S$. cerevisiae mating, pheromone gradients are generated by the secretion of a- and $\alpha$-factor. There are three factors that are likely to be important for the generation of pheromone gradients: first, the physical characteristics of the mating pheromone; second, the site(s) of pheromone secretion or export; and third, the distribution of proteases that degrade mating pheromone. The shape of a mating pheromone gradient is likely to be dependent on the diffusibility of the mating peptide, and as a-factor is farnesylated, its diffusion in aqueous environments is decreased. This posttranslational modification may be critical in hydrophobic milieu, such as cellular membranes or natural habitats including biofilms. The increased hydrophobicity and reduced diffusibility of a-factor (Caldwell et al. 1994; Khouri et al. 1996) may contribute to the further sharpening (increasing the steepness) or stabilizing of its gradient compared with that of $\alpha$-factor. Furthermore, pheromones are likely to be secreted ( $\alpha$-factor) or exported (a-factor via the Ste6 transporter) from the tip of shmoos (Kuchler et al. 1993), and this site-specific release will dictate the shape of the gradient. Site-specific secretion or export will generate anisotropy in the mating pheromone gradient, which should provide information on cell position. Specifically, the location of a particular shmoo tip should be evident by the position, direction, and shape of its pheromone gradient.

Mating pheromone proteases are also secreted, yet little is known about whether their secretion occurs at a specific site. Proteases, such as the barrier aspartyl protease Barl, limits the distance of the $\alpha$-factor tridecapeptide gradient (Barkai et al. 1998). Similarly, a protease activity that degrades a-factor has been identified in MAT $\alpha$ cells (Marcus et al. 1991). Each of these pheromone proteases are expressed only in receiving cells. The $\alpha$-factor protease Barl is largely secreted, with $95 \%$ of the Bar1 activity found extracellularly (Ciejek and Thorner 1979; Ballensiefen and Schmitt 1997). This protease has also been found, however, attached to the cell wall (Moukadiri et al. 1999). a-factor protease activity is also essentially cell-associated (Marcus et al. 1991). A gradient of secreted $\alpha$-factor protease, or cell-associated a-factor protease, is likely to sharpen the pheromone gradient. Finally, pheromone degradation via a cell-associated protease has been proposed as a means for distinguishing potential mating partners amongst many cells (Barkai et al. 1998).

\section{SENSING AND DETECTION}

\section{Pheromone Receptors}

Yeast cells must detect a mating pheromone gradient to initiate a range of cellular responses. Critical for such detection are the classical seven-transmembrane domain receptors coupled to hetero-trimeric G-proteins (for review, see Xue et al. 2008), the a-cell specific Ste2 (which binds $\alpha$-factor), and the $\alpha$-cell specific Ste3 (which binds a-factor). These receptors do not share substantial sequence homology. Transcription of both receptors is rapidly increased on addition of the respective pheromone (Hagen and Sprague 1984; Hartig et al. 1986). Haploid a-cells have $\sim 10,000$ cell-surface binding sites for $\alpha$-factor with a $\mathrm{K}_{\mathrm{d}}$ of 4-6 nM (Jenness et al. 1986; Stefan et al. 1998). This high-affinity receptor resting state is converted to a low-affinity state, with an $\sim 10$-fold increase in ligand off-rate and corresponding increase in $\mathrm{K}_{\mathrm{d}}$, in the presence of GTP $\gamma$ S (Blumer and Thorner 1990).

When haploid a-cells bind $\alpha$-factor, Ste2 receptors are internalized with a $t_{\text {avg. }}$ of $\sim 8$ min (Schandel and Jenness 1994) and reappear on the cell surface after $\sim 60$ min (Jenness and Spatrick 1986; Ayscough and Drubin 1998; Stefan et al. 1998). Both a- and $\alpha$-factor receptors have substantial-183 and 133 amino acids, respectively—cytoplasmic carboxy termini. Truncation of the Ste2 carboxyterminal 105 amino acids results in a $\sim$ fivefold increase in cell surface pheromone binding sites, a 10-fold increase in pheromone sensitivity, and a defect in pheromone induced morphogenesis (Konopka et al. 1988). Ste2 receptors also oligomerize in vivo, yet this association does not depend on ligand 
nor hetero-trimeric G-protein (Overton and Blumer 2000; Yesilaltay and Jenness 2000). Ste2 transmembrane domains five and six together with the intervening third intracellular loop are important for G-protein activation, via $\mathrm{G} \alpha$ (Konopka and Jenness 1991; Clark et al. 1994; Stefan and Blumer 1994; Dube et al. 2000; Celic et al. 2003; Lin et al. 2003). The carboxy-terminal cytoplasmic domain of the receptor interacts with $\mathrm{G} \alpha$ in a preactivation complex (Dosil et al. 2000; Wu et al. 2004). The extracellular end of transmembrane domain 1, together with the extracellular loops 1 and 2, interact directly with pheromone (Son et al. 2004; Hauser et al. 2007). Although pheromone receptors are necessary for detecting pheromone, it is likely that their internalization and recycling play an important role in signal amplification and desensitization.

In the absence of mating pheromone, both pheromone receptors localize uniformly over the cell surface as well as endosomal and vacuole compartments (Jackson and Hartwell 1990b; Davis et al. 1993; Ayscough and Drubin 1998; Stefan and Blumer 1999). During the later stages of mating, Ste2 is localized to mating projections, raising the possibility that this polarized distribution is important for chemotropic growth (Jackson et al. 1991). In cells treated with isotropic saturating pheromone concentrations, little receptor was observed on the cell surface after 20 min and instead a punctate cytoplasmic distribution was observed (Ayscough and Drubin 1998). Finally, after $\sim 90 \mathrm{~min}$, the receptor was localized to the mating projection, enriched at the tip (Ayscough and Drubin 1998) (Fig. 1). In these conditions, the actin cytoskeleton is required for Ste2 polarization (Ayscough and Drubin 1998). It is likely that the actin cytoskeleton is critical for receptor exocytosis and endocytosis, which are important for the receptor polarization (via targeting and maintenance). It will be essential to follow receptor distribution during chemotropism (in response to defined pheromone gradients and during mating) to better understand the role of receptor secretion, endocytosis, and polarization during directional growth.
Chemical Gradients and Chemotropism in Yeast

\section{Hetero-trimeric G-protein}

The pheromone receptor functions as a guanine nucleotide exchange factor for $\mathrm{G} \alpha$. On pheromone binding, the receptor catalyzes the exchange of GDP for GTP in the G $\alpha$ GDP G $\beta \gamma$ complex, resulting in the dissociation of G $\alpha$.GTP from G $\beta \gamma$ (reviewed in Dohlman and Thorner 2001; Dohlman 2002). G $\alpha$ and $\mathrm{G} \beta \gamma$ are then able to associate and activate downstream effectors. This signaling competent state of the $\mathrm{G} \alpha$ and $\mathrm{G} \beta \gamma$ subunits exists

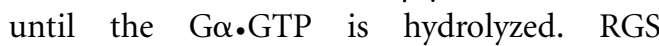
(Regulators of $G$ protein Signaling) proteins such as Sst2, function as GTPase accelerating proteins or GAPs facilitating G $\alpha$ GTP hydrolysis (Apanovitch et al. 1998; DiBello et al. 1998). Receptor and hetero-trimeric G-protein turnover, either by cellular uptake (endocytosis) or posttranslational modification (including modifications that target proteins for degradation) also contribute to down-regulation.

Initial studies indicated that released $G \beta \gamma$ functions in a positive fashion by initiating a range of pheromone responses (Jahng et al. 1988; Whiteway et al. 1989; Cole et al. 1990; Nomoto et al. 1990) including cell cycle arrest, gene transcription, cell morphology changes, and chemotropic growth (Figs. 2 and 3). More recently, however, several studies have revealed that $\mathrm{G} \alpha$, in addition to its role as a negative regulator (via inactivation of released $G \beta \gamma$ ), can also activate signaling (Metodiev et al. 2002; Slessareva et al. 2006).

The G $\alpha, G \beta$, and G $\gamma$ subunits are all localized to the plasma membrane and internal membranes, with $G \alpha$ and $G \gamma$ each having dual posttranslational lipid modifications that result in membrane association (Song et al. 1996; Hirschman et al. 1997). These modifications are necessary for function, with $\mathrm{G} \alpha$ being both palmitoylated and myrisotoylated (Stone et al. 1991; Dohlman et al. 1993; Song and Dohlman 1996; Song et al. 1996; Manahan et al. 2000) and G $\gamma$ being palmitoylated and prenylated (Grishin et al. 1994; Whiteway and Thomas 1994; Hirschman and Jenness 1999). Although $G \alpha$ is thought to associate with the pheromone receptors via its 
R.A. Arkowitz

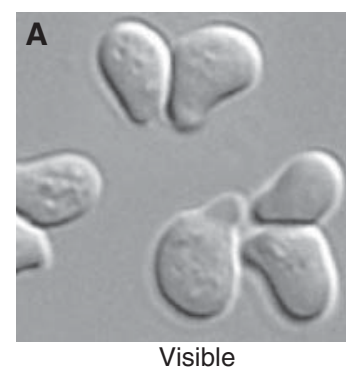

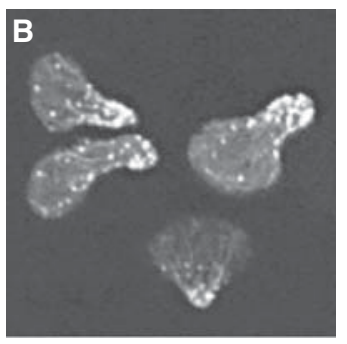

Actin cytoskeleton

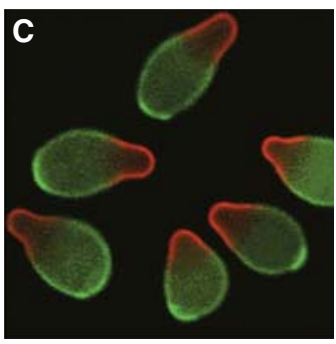

New cell growth

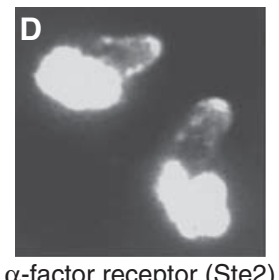

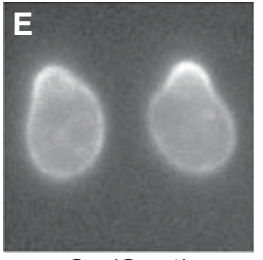

$\mathrm{G} \alpha(\mathrm{Gpa} 1)$

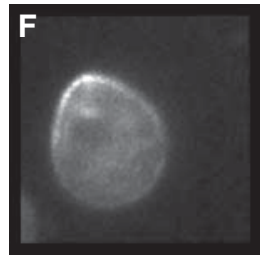

$\mathrm{G} \beta($ Ste4)

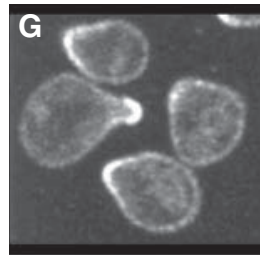

G $\gamma($ Ste18)

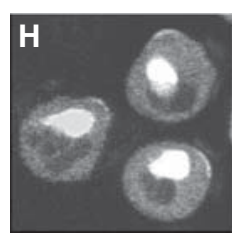

Far1

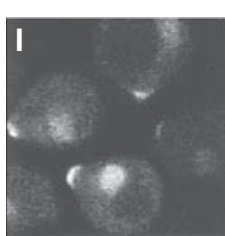

Cdc24

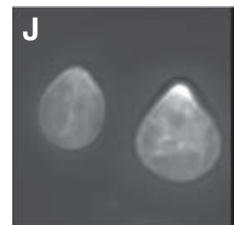

Cdc42

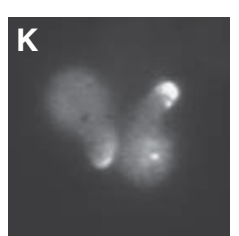

Bni1

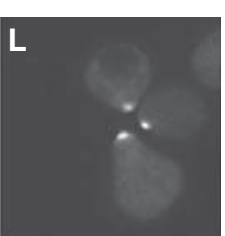

Spa2

Figure 1. Localization of actin cytoskeleton, regions of growth and proteins required for yeast chemotropism in yeast cells treated with mating pheromone. (A) Wild-type MATa yeast cells treated with $\alpha$-factor for 2 h. Differential interference contrast image of shmoo. (B) Wild-type yeast MATa cells treated with $\alpha$-factor for $2 \mathrm{~h}$ and then the actin cytoskeleton was stained with Alexa-568 phalloidin. Fluorescence images are maximum intensity projections of $\mathrm{Z}$ sections. $(C)$ Regions of new cell wall growth (red) and old growth (green) in wild-type MATa shmoos. Alexa-Fluor 488 concanavalin A-labeled cells (green) were incubated in YEP $0.1 \%$ glucose in the presence of $\alpha$-factor for $4 \mathrm{~h}$ and then stained with Alexa-Fluor 594 concanavalin A (red). (Reprinted from Nern and Arkowitz 2000a.) (D) Localization of $\alpha$-factor receptor Ste2-GFP in MATa cells incubated $2 \mathrm{~h}$ with $\alpha$-factor. The brightly fluorescent structures within the cells are the vacuoles, which

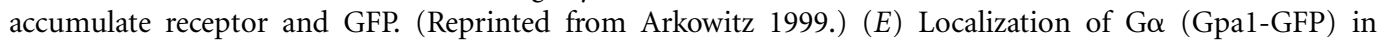
elutriated MATa cells incubated $1 \mathrm{~h}$ with $\alpha$-factor (kindly provided by D. Stone). (F) Localization of G $\beta$ (Ste4-GFP) in elutriated MATa cells incubated $1 \mathrm{~h}$ with $\alpha$-factor (kindly provided by D. Stone). $(G)$ Localization of G $\gamma$ (Ste18-GFP) in MATa cells incubated $2 \mathrm{~h}$ with $\alpha$-factor. (Reprinted from Nern and Arkowitz 2000a.) (H) Localization of Farl-GFP in MATa $c d c 28-13$ cells that were arrested at $37^{\circ} \mathrm{C}$ and then incubated with $\alpha$-factor and shifted to $25^{\circ} \mathrm{C}$ for $30 \mathrm{~min}$. (Reprinted, with permission, from Nern and Arkowitz 2000b.) (I) Localization of Cdc24-GFP in MATa $c d c 28-13$ cells that were arrested at $37^{\circ} \mathrm{C}$ and then incubated with $\alpha$-factor and shifted to $25^{\circ} \mathrm{C}$ for $30 \mathrm{~min}$. (Reprinted, with permission, from Nern and Arkowitz 2000b.) (J) Localization of GFP-Cdc42 in MATa cells incubated $2 \mathrm{~h}$ with $\alpha$-factor. (Reprinted, with permission, from Barale et al. 2006.) (K) Localization of Bnil-GFP in MATa cells incubated $2 \mathrm{~h}$ with $\alpha$-factor. (Reprinted, with permission, from Matheos et al. 2004 [C) Matheos et al. 2004; originally published in J. Cell Biol. doi: 10.1083/jcb.200309089.]) (L) Localization of Spa2-GFP in MATa cells incubated $2 \mathrm{~h}$ with $\alpha$-factor. (Reprinted, with permission, from Nern and Arkowitz 2000a.) 
Chemical Gradients and Chemotropism in Yeast

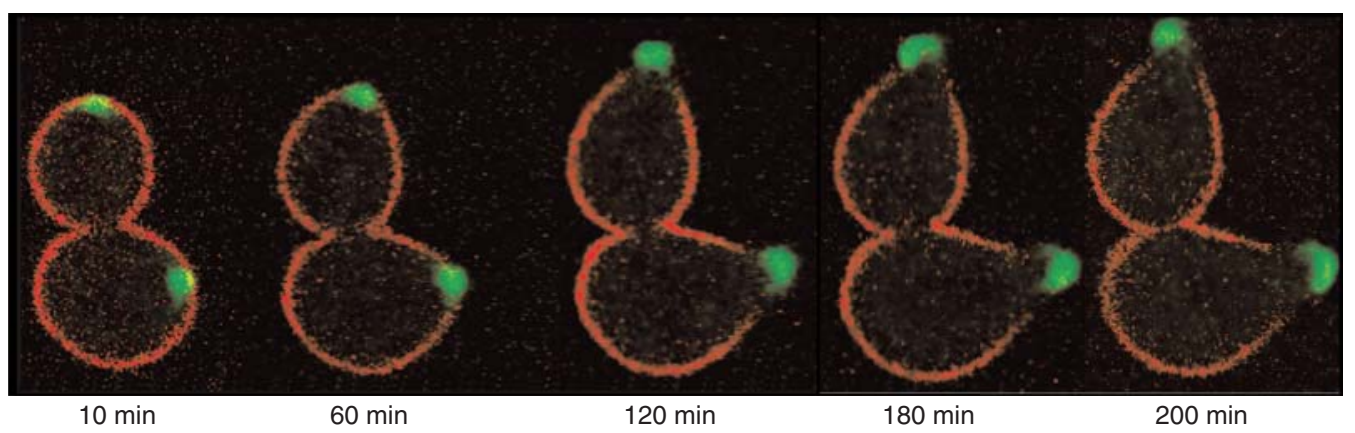

Figure 2. Cell morphology changes in response to mating pheromone. Spa2-GFP localization (green) in cell treated with pheromone for indicated times. Rhodamine concanavalin A-labeled cells expressing Spa2-GFP were imaged on SC-ura agar containing 30- $\mu \mathrm{M} \alpha$-factor. Images are projections (arithmetic average) of 3-5 optical 1- $\mu \mathrm{m}$ z-sections. (Reprinted, with permission, from Nern and Arkowitz 2000a.)

carboxy terminus (Hirsch et al. 1991), its membrane localization does not require G $\beta \gamma$ or receptors (Blumer and Thorner 1990; Song et al. 1996). Conversely, although $\mathrm{G} \alpha$ is required for $\mathrm{G} \beta \gamma$ membrane localization, the pheromone receptor is not required (Song et al. 1996; Hirschman et al. 1997). The localization of the $\mathrm{G} \alpha$ (Metodiev et al. 2002), G $\beta$ (Kim et al. 2000), and G $\gamma$ (Nern and Arkowitz 2000a; Moore et al. 2008) has been examined in both isotropic pheromone concentrations $(\mathrm{G} \alpha$ and $\mathrm{G} \beta)$ and in pheromone gradients during mating or generated artificially $(\mathrm{G} \gamma)$ (Fig. 1). These three proteins localize preferentially to the mating projection (also appear on internal membranes), similar to the distribution of the pheromone receptor (Jackson et al. 1991; Ayscough and Drubin 1998; Moore et al. 2008). The subcellular distribution of the different hetero-trimeric G-protein subunits and their relationship to one another during the mating process (chemotropic growth) has not been quantitatively examined at high temporal and spatial resolution. Such analyses will be important for understanding the requirements and feedback loops that are necessary for chemotropic growth.

\section{Detection of Small Differences in Ligand Concentration}

It is highly unlikely that yeast cells use a temporal mechanism to detect small differences in ligand concentration given that they grow relatively slow, i.e., maximally their $5 \mu \mathrm{m}$ diameter after $\sim 6 \mathrm{~h}$ in pheromone (Segall 1993; Vallier et al. 2002). It is largely accepted, that yeast cells use a spatial detection mechanism, as is the case for leukocytes, in which pheromone concentration is compared on two sides of the cell. If a gradient is generated by a micropipet (Fig. 4), using a 70-nM $\alpha$-factor solution, released at a rate of $2 \mathrm{~nL} / \mathrm{min}$ and cells are positioned $\sim 50 \mu \mathrm{m}$ from the tip of the micropipet, then the cell half closest to the pipet is estimated to experience $11.5-\mathrm{nM} \alpha$-factor and that farthest from the pipet 10.2-nM $\alpha$-factor (Segall 1993; Vallier et al. 2002). Assuming a uniform distribution of receptors, $\sim 66$ more receptors would have pheromone bound closest to the gradient compared with the opposite side (a difference in receptor occupancy of $\sim 1.3 \%$ ). A recent study using microfluidics chambergenerated pheromone gradients (Fig. 4) has extended these calculations based on the observation that yeast cells can sense the direction of the pheromone gradient with a slope relative to the average concentration ([ pheromone slope $] /\left[\right.$ pheromone $_{\text {conc. }}$ at the mid point]) as shallow as $0.1 \% / \mu \mathrm{m}^{-1}$ (Moore et al. 2008); a difference of $0.5 \%$ in ligand concentration from the cell front and back. When cells are in a $0-1000-\mathrm{nM}$ gradient at an average concentration of $500 \mathrm{nM}$, then the absolute slope is $2.5 \mathrm{nM} / \mu \mathrm{m}$. This results in 4951 and 4950 receptors occupied in the front 
R.A. Arkowitz

A
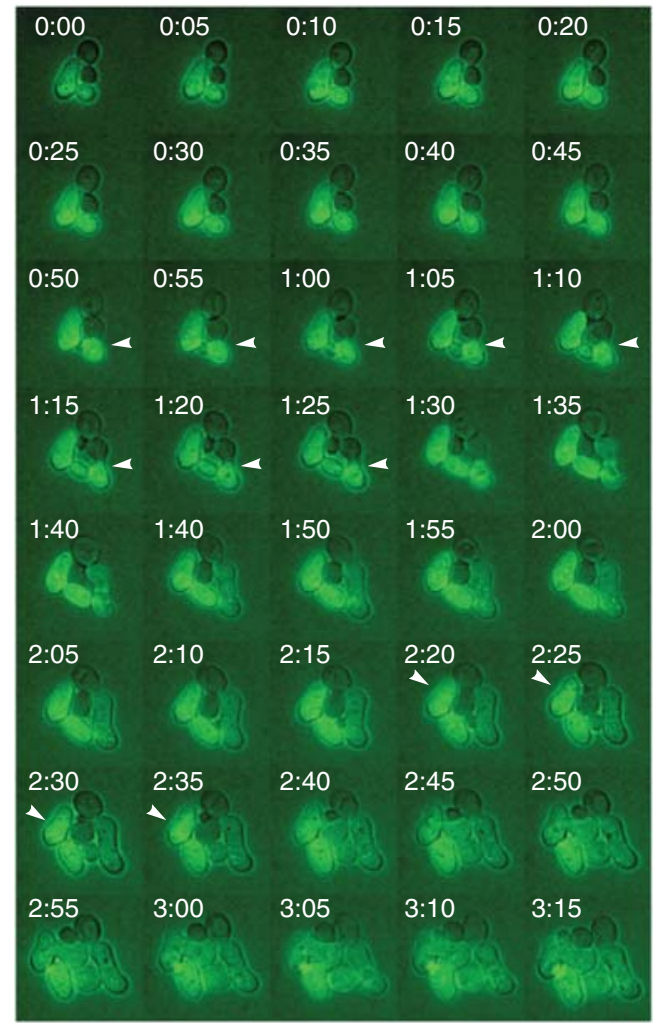

B

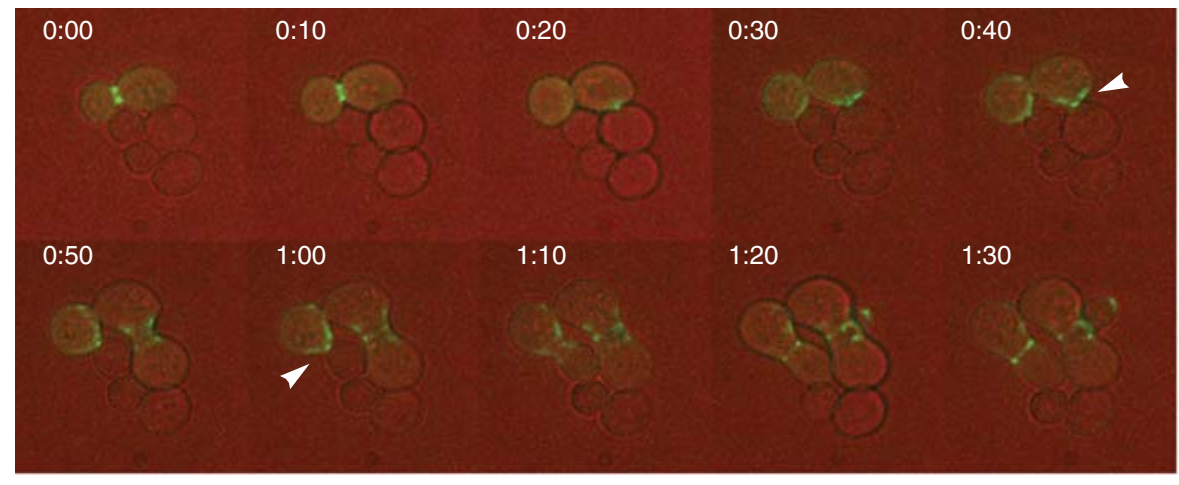

Figure 3. Cell morphology changes and chemotropism during yeast mating. (A) Time-lapse images of wild-type $M A T \alpha$ cells mating with GFP-Bud1 expressing wild-type MATa cells (green) mating partner. Images taken at indicated times $\left(\right.$ at $30^{\circ} \mathrm{C}$ ) with visible (black) and fluorescence (green) shown. Note cell pairs indicated by arrows are polarized and grow toward one another (0:50-1:25 and 2:20-2:35 times). These cells pairs fuse to form zygotes at 1:30 and 2:40, respectively, and fluorescence signal in MATa cells can now be observed in $M A T \alpha$ cells. (Reprinted, with permission, from Barale et al. 2004.) (B) Time-lapse images of wild-type MAT $\alpha$ cells mating with GFP-Bud2 expressing MATa cells (green) mating partner. Images taken at indicated times (at $30^{\circ} \mathrm{C}$ ) with DIC (red) and fluorescence (green) shown. Images are maximum intensity projections 5 optical $0.5-\mu \mathrm{m}$ z-sections that were deconvolved with SoftWoRx software. Cell pairs that fuse to form zygote are indicated by arrows. These cells are polarized and grow toward one another (0:20-0:40 and 0:40-1:00 times) before fusing. 
A

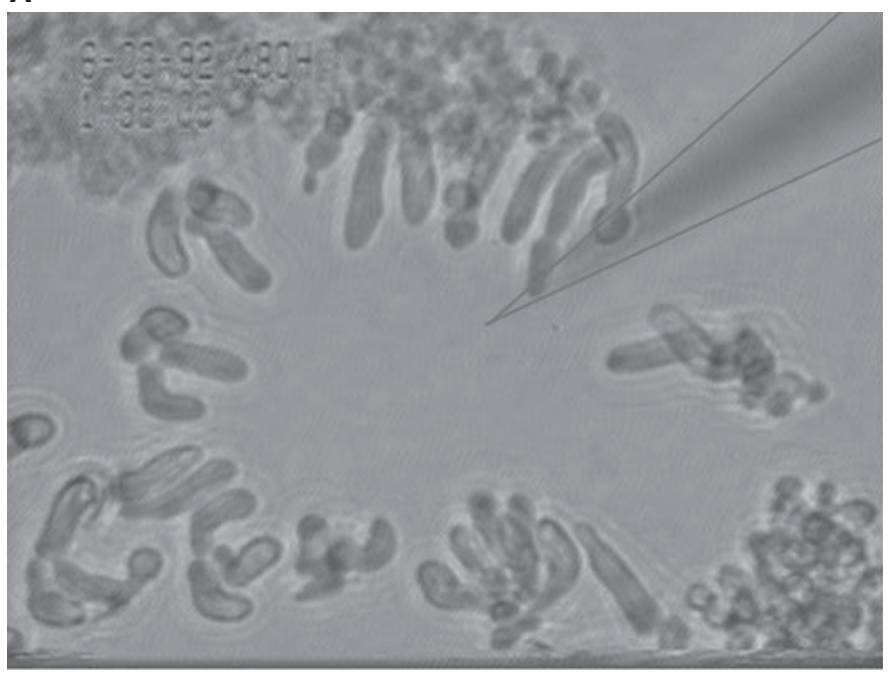

B

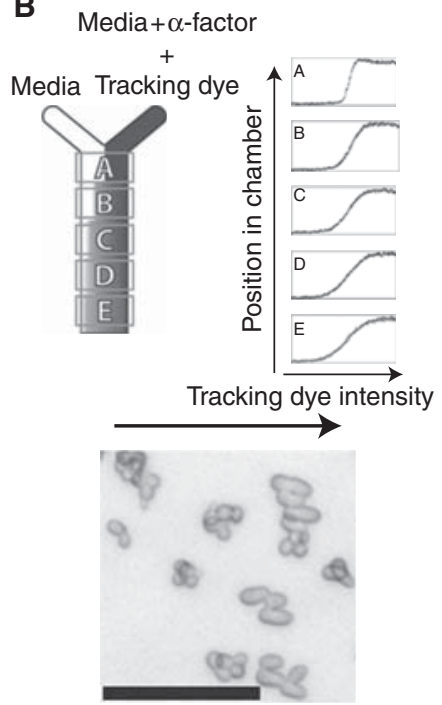

Figure 4. Chemotropic response of yeast cells to artificially generated pheromone gradients. $(A)$ Wild-type cells exposed to a micropipet-generated pheromone gradient. The micropipet contained $67 \mathrm{nM}$ mating pheromone and this image was taken after $\sim 9 \mathrm{~h}$ exposure to the gradient at $30^{\circ} \mathrm{C}$. The pipet is the elongated out-of-focus object originating in the upper right corner, which is outlined in black. Image kindly provided by J. Segall (Segall 1993 [CNational Academy of Sciences]). (B) Mating pheromone gradient generated in a microfluidics chamber. (Adapted from Moore et al. 2008.) Schematic diagram (upper left) of microfluidics Y-device in which media alone is in the left inlet and media containing $\alpha$-factor together with and Dextran-3000-TRITC (tracking dye) in the right inlet. This results in a gradient across the width of the chamber via diffusion. Five positions descending the length of the main channel, denoted A to E, are indicated and visualized. The gradient slope varies depending on the position along the length of the central chamber (upper right). Note that the gradient is shallower as one progresses down the chamber (the tracking dye and $\alpha$-factor have more time to diffuse). In position A of microfluidics chamber in $0-100-\mathrm{nM}$ gradient, after $4 \mathrm{~h}$, a narrow band of bar1 $\Delta$ cells in the middle of the chamber were almost perfectly aligned to source of the gradient (bottom). The direction of the gradient is from left (low) to right (high), shown by the black arrow and scale bar $(50 \mu \mathrm{m})$.

half and the back half of the cell, respectively! Strikingly, a barl mutant strain was able to weakly orient (cosine of the angle of orientation $\sim 0.2$ : angle of $\sim 78^{\circ}$ ) to a $0-1000-\mathrm{nM}$ pheromone gradient at $>900-\mathrm{nM}$ pheromone, in which all receptors should be saturated. Furthermore, this elegant microfluidics study revealed that bar1 mutants are able to orient their growth to a gradient over almost three orders of magnitude $(4 \mathrm{nM}-930 \mathrm{nM})$. The calculations of receptor occupancy and gradient detection assume constant number of pheromone receptors, i.e., do not take into consideration receptor induction, exocytosis, and endocytosis. These different processes undoubtedly affect the real difference in receptor occupancy in a pheromone gradient, yet nevertheless, an extremely small difference in ligand concentration is likely to be detected during mating. How this very small difference is translated into much steeper intracellular gradient(s) remains a fundamental question.

Cellular responses can either be dictated by absolute pheromone concentrations or the fractional change in concentration ( $\Delta$ [pheromone $] / \Delta$ distance, i.e., gradient steepness) across the cell (Walter et al. 1990; Goodhill 1998; Goodhill and Baier 1998). In nerve growth cones (Isbister et al. 2003) and in round immobile latrunculin-treated Dictyostelium discoideum (Janetopoulos et al. 2004), directional responses are dictated by the gradient steepness as has also been observed in chemotaxing neutrophils (Zigmond 1977). 
In yeast, directional growth has been shown to occur in response to the fractional gradient and not the absolute pheromone concentration (Paliwal et al. 2007). Fractional gradient is the ratio of the pheromone concentration gradient (offset by a gradient value $\gamma_{0} ; \gamma-\gamma_{0}$ ), and the difference between the mean pheromone and minimum pheromone concentration necessary for shmoo formation, and can be thought of as the steepness of the gradient divided by the pheromone concentration. Accuracy of gradient sensing was highest at low pheromone concentrations and high gradients (Segall 1993; Paliwal et al. 2007; Moore et al. 2008). Accuracy of gradient sensing is the cosine of the angle of the mating projection relative to the pheromone gradient; a value of one indicates perfect alignment. Indeed, gradient sensing appears to be optimal near the pheromone concentration that equals the receptor $\mathrm{K}_{\mathrm{d}}$ (Segall 1993; Paliwal et al. 2007; Moore et al. 2008). Precision of gradient sensing has been defined as the root mean square (rms) of several cells between the angles of observed mating projections and the direction of the gradient, with precision increasing as rms decreases (Paliwal et al. 2007). Furthermore, the precision of gradient sensing is constant at a constant fractional gradient and increases as the fractional gradient increases (Paliwal et al. 2007). It is thought that the combination of constant pheromone release (although this has not been validated experimentally), together with first-order reaction of pheromone degradation by the extracellular proteases, should result in an exponential gradient (Barkai et al. 1998). Hence, as cells grow toward the source of an exponential gradient, both the gradient steepness and the pheromone concentration would increase, resulting in a constant fractional gradient and hence constant precision of gradient sensing (Paliwal et al. 2007). Although this makes biological sense, it remains to be seen if the precision of directional sensing is indeed constant throughout the mating process.

In response to a micropipet-generated pheromone gradient (Fig. 4), orientation accuracy of yeast cells increases over time (cosine of the angle of orientation increasing from $\sim 0.55$; angle of $\sim 57^{\circ}$ to 0.85 ; angle of $\sim 32^{\circ}$ from shmoo formation to $\sim 5 \mathrm{~h}$ later) (Vallier et al. 2002). These results suggest that mating projection reorientation can occur over time (Paliwal et al. 2007). Very recently, studies using microfluidics chamber-generated pheromone gradients (Fig. 4) confirmed that directional accuracy improves over time (Moore et al. $2008)$. In the range of $5-40 \mathrm{nM}$ of $\alpha$-factor (in a $0-100 \mathrm{nM}$ gradient), cells formed broad mating projections which reoriented toward the gradient, with an orientation accuracy of $\sim 0.4$ (angle of $66^{\circ}$ ) to $\sim 0.6$ (angle of $53^{\circ}$ ) at 2 and $6 \mathrm{~h}$, respectively. At pheromone concentrations greater than $50 \mathrm{nM}$, cells frequently formed a second mating projection that was more oriented than the first (Moore et al. 2008). Assuming that the pheromone gradient is linear, then this increase in the precision of gradient sensing over time can be explained by an increase in the fractional gradient: The pheromone concentration should increase $\sim 10 \%-20 \%$, given the above parameters at an average pheromone concentration of the receptor $\mathrm{K}_{\mathrm{d}}$ over one to two cell lengths.

Using a micropipet-generated pheromone gradient, cells lacking the Bar1 protease orient similarly to wild-type cells, at low pheromone concentration (Segall 1993). The bar $1 \Delta$ mutant was extensively characterized in a recent microfluidics chamber study (Moore et al. 2008). Compared with a wild-type $B A R 1^{+}$strain, barls cells oriented to $0-100 \mathrm{nM}$ and $0-$ $1000 \mathrm{nM}$ pheromone gradients with decreased accuracy. Furthermore, Bar1 functioned even in the constant flow $(1 \mu \mathrm{L} / \mathrm{min})$ in $\sim 1 \mu \mathrm{L}$ chambers, consistent with cell-wall associated protease (Moukadiri et al. 1999). Surprisingly, both $B A R 1^{+}$and bar1 $\Delta$ cells exhibited the best orientation at [ pheromone $]_{\text {avg. }}$ that were equivalent to the receptor $\mathrm{K}_{\mathrm{d}}$ (Moore et al. 2008). However, it should be pointed out that in the case of the bar $1 \Delta$ cells, this was in a relatively steep portion of a $0-10 \mathrm{nM}$ pheromone gradient, whereas for $B A R 1^{+}$cells, this was at a shallow portion of a $0-100 \mathrm{nM}$ pheromone gradient, suggesting that Barl facilitates sensing of shallow gradients. Furthermore, in a microfluidic chamber-generated 0-100 nM pheromone 
gradient, sst $2 \Delta$ bar1 $\Delta$ cells are incapable of orienting toward the gradient (Moore et al. 2008). Consistent with results using a micropipet-generated gradient (Segall 1993), at low pheromone concentrations $(0-10 \mathrm{nM}$ gradient), the accuracy of orientation of bar $1 \Delta$ sst $2 \Delta$ cells was less than the corresponding barl $\Delta$ cells in the same conditions (Moore et al. 2008).

\section{CELLULAR RESPONSES}

\section{Gene Induction}

In response to pheromone gradients, cells induce gene transcription, undergo cell cycle arrest, change shape, and grow toward a mating partner. The first three responses can occur during mating, in which a pheromone gradient is present, as well as in an isotropic pheromone concentration. The latter response, however, only occurs when a pheromone gradient is present. The optimum mating pheromone concentration for gene induction, cell cycle arrest, and cell shape changes does not seem to differ substantially between isotropic and gradient pheromone conditions (Paliwal et al. 2007; Moore et al. 2008). Recently, it has been shown that the pheromone concentration range of gradients at which cells are sensitive for induction of the mating-specific gene FUS1 coincides with that for directional growth (Paliwal et al. 2007; Moore et al. 2008). This may be because some genes essential for gradient sensitivity are induced by this MAP kinase cascade or that, despite the ability to genetically separate the MAP kinase and chemotropism pathways (Schrick et al. 1997; Strickfaden and Pryciak 2008), there may be cross-talk between these pathways. More than 100 genes are induced by pheromone (Erdman et al. 1998). Genes whose induction is more efficient with a pheromone gradient than with an isotropic pheromone concentration would be ideal candidates for modulators of the chemotropic response.

\section{Cell Shape Changes}

In yeast, as in many organisms, changes in cell shape can be separated from directional growth. In isotropic pheromone conditions, yeast cells become elongated and form shmoos (Fig. 2). A range of proteins are necessary for these morphology changes, some of which are mating-specific, and others are more generally involved in cell polarity yet appear to have specific functions in response to pheromone (Table 1). This process is referred to as "default" polarization (Madden and Snyder 1992; Dorer et al. 1995) and the previous bud site provides the spatial cue for mating projection formation. In addition to the receptor and hetero-trimeric G-protein, the pheromone-dependent MAP kinase Fus3 and the pheromone-induced proteins Afr1 and Pea2 are required for shmoo formation (Chenevert et al. 1994; Valtz and Herskowitz 1996; Matheos et al. 2004). Other proteins required for cell polarity are particularly important for morphology changes in response to pheromone. Pheromone-dependent cell-shape changes can be separated from chemotropic growth. This may be, in part, because of the fact that most studies on cell-shape changes have been performed in saturating pheromone concentrations that may mask chemotropic effects.

\section{Directional Growth}

Different assays have shown that the pheromone receptor, the hetero-trimeric G-protein, and several proteins that bind specifically to the released $\mathrm{G} \alpha$ and $\mathrm{G} \beta \gamma$ convey the spatial information from the pheromone gradient to the downstream proteins critical for pheromonedependent morphology changes (Table 1). Elegant studies showed that both MATa and $M A T \alpha$ cells choose between potential mating partners (Jackson and Hartwell 1990a; Jackson and Hartwell 1990b). Specifically, each cell type chooses the mating partner that produces the highest level of pheromone. The simplest model to account for this is that cells detect a mating pheromone gradient and orient growth toward the cell producing the steepest gradient (Fig. 3). In these studies, two assays were used: the competition mating assay and the discrimination assay. In both assays, a cell 
R.A. Arkowitz

Table 1. Proteins involved in directional sensing, polarization, and growth

\begin{tabular}{|c|c|c|c|}
\hline Gene & Function & Process & $\begin{array}{l}\text { Pheromone } \\
\text { defect }\end{array}$ \\
\hline \multicolumn{4}{|c|}{ Directional sensing and oriented growth } \\
\hline STE2 & $\begin{array}{l}\alpha \text {-factor seven-TMD G-protein } \\
\text { coupled receptor }\end{array}$ & $\begin{array}{l}\text { Initiates all pheromone signaling } \\
\text { responses }\end{array}$ & IC, DC, SC \\
\hline STE3 & $\begin{array}{l}\text { a-factor seven-TMD G-protein } \\
\text { coupled receptor }\end{array}$ & $\begin{array}{l}\text { Initiates all pheromone signaling } \\
\text { responses }\end{array}$ & IC, SC \\
\hline GPA1 & $\begin{array}{l}\text { Hetero-trimeric G } \alpha \text { subunit that } \\
\text { binds GTP }\end{array}$ & $\begin{array}{l}\text { Negatively and positively regulates } \\
\text { signaling (gene induction, cell } \\
\text { shape changes, and } \\
\text { chemotropism) }\end{array}$ & IC, SC \\
\hline STE4 & $\begin{array}{l}\text { Hetero-trimeric } G \beta \text { subunit } \\
\text { which forms dimer with } G \gamma\end{array}$ & $\begin{array}{l}\text { Positively regulates signaling (gene } \\
\text { induction, cell shape changes, and } \\
\text { chemotropism) }\end{array}$ & IC, SC \\
\hline STE18 & $\begin{array}{l}\text { Hetero-trimeric } \mathrm{G} \gamma \text { subunit } \\
\text { which forms dimer with } \mathrm{G} \beta\end{array}$ & $\begin{array}{l}\text { Positively regulates signaling (gene } \\
\text { induction, cell shape changes, and } \\
\text { chemotropism) }\end{array}$ & IC, SC \\
\hline FAR1 & $\begin{array}{l}\text { Cyclin-dependent kinase } \\
\text { inhibitor }\end{array}$ & $\begin{array}{l}\text { Mediates pheromone-dependent cell } \\
\text { cycle arrest and chemotropism }\end{array}$ & IC, DC \\
\hline$C D C 24$ & $\begin{array}{l}\text { Cdc42 guanine nucleotide } \\
\text { exchange factor (activator) }\end{array}$ & $\begin{array}{l}\text { Pheromone-dependent cell shape } \\
\text { changes and chemotropism }\end{array}$ & IC, DC, SC \\
\hline FUS3 & $\begin{array}{l}\text { Pheromone-dependent MAP } \\
\text { kinase }\end{array}$ & $\begin{array}{l}\text { Pheromone-dependent gene } \\
\text { induction and chemotropism }\end{array}$ & IC, DC, SC \\
\hline KSS1 & $\begin{array}{l}\text { MAP kinase involved in } \\
\text { filamentous growth and } \\
\text { pheromone response }\end{array}$ & $\begin{array}{l}\text { Pheromone-dependent gene } \\
\text { induction and chemotropism }\end{array}$ & $\mathrm{DC}(k s s 1$ barl $)$ \\
\hline$B A R 1$ & $\begin{array}{l}\text { Barrier protease, degrades } \\
\alpha \text {-factor }\end{array}$ & $\begin{array}{l}\text { Allows cells to recover from } \\
\text { pheromone arrest }\end{array}$ & IC, DC \\
\hline SST2 & $\begin{array}{l}\text { Regulators of G protein signaling } \\
\text { (RGS)-G } \alpha \text { GTPase accelerating } \\
\text { protein }\end{array}$ & $\begin{array}{l}\text { Desensitizes or dampens pheromone } \\
\text { induced signaling }\end{array}$ & IC, DC \\
\hline$A C T 1$ & Actin & $\begin{array}{l}\text { Cytoskeleton, membrane traffic, and } \\
\text { cell polarity }\end{array}$ & IC \\
\hline MYO2 & Type V myosin & Actin-based cargo transport & IC \\
\hline $\mathrm{CHC1}$ & Clathrin heavy chain & Intracellular transport & IC \\
\hline \multicolumn{4}{|c|}{ Gene induction } \\
\hline STE20 & $\begin{array}{l}\text { PAK family kinase (Cdc42 } \\
\text { effector) }\end{array}$ & $\begin{array}{l}\text { Pheromone-dependent gene } \\
\text { induction }\end{array}$ & GI \\
\hline STE5 & $\begin{array}{l}\text { Pheromone-dependent MAP } \\
\text { kinase scaffold protein (binds } \\
\text { Ste11, Ste7, and Fus3) }\end{array}$ & $\begin{array}{l}\text { Pheromone-dependent gene } \\
\text { induction }\end{array}$ & GI \\
\hline STE11 & $\begin{array}{l}\text { Pheromone-dependent MAP } \\
\text { kinase kinase kinase }\end{array}$ & $\begin{array}{l}\text { Pheromone-dependent gene } \\
\text { induction, phosphorylates Ste7 }\end{array}$ & GI \\
\hline STE7 & $\begin{array}{l}\text { Pheromone-dependent MAP } \\
\text { kinase kinase }\end{array}$ & $\begin{array}{l}\text { Pheromone-dependent gene } \\
\text { induction, phosphorylates Fus } 3\end{array}$ & GI \\
\hline STE12 & $\begin{array}{l}\text { Pheromone-dependent MAP } \\
\text { kinase transcription factor }\end{array}$ & $\begin{array}{l}\text { Pheromone-dependent gene } \\
\text { induction }\end{array}$ & GI \\
\hline FUS1 & Pheromone-induced protein & Required for cell fusion & $\mathrm{CF}$ \\
\hline FUS2 & Pheromone-induced protein & Required for cell fusion & $\mathrm{CF}$ \\
\hline
\end{tabular}


Chemical Gradients and Chemotropism in Yeast

Table 1. Continued

\begin{tabular}{|c|c|c|c|}
\hline Gene & Function & Process & $\begin{array}{l}\text { Pheromone } \\
\text { defect }\end{array}$ \\
\hline \multicolumn{4}{|c|}{ Cell shape changes/polarization } \\
\hline CDC42 & Rho GTP binding protein & Cell polarity & $\mathrm{SC}^{\mathrm{a}}$ \\
\hline RHO1 & Rho G-protein & Cell polarity & \\
\hline$B E M 1$ & $\begin{array}{l}\text { SH3 domain-containing scaffold } \\
\text { protein }\end{array}$ & Cell polarity & SC \\
\hline AFR1 & Pheromone-induced protein & Shmoo formation & SC \\
\hline PEA2 & Pheromone-induced protein & Shmoo formation & SC \\
\hline BNI1 & Formin, actin cable formation & Cell polarity & SC \\
\hline SPA2 & Scaffold protein & Cell polarity & $\mathrm{SC}$ \\
\hline GIC1 & $\begin{array}{l}\text { CRIB domain-containing Cdc42 } \\
\text { effector }\end{array}$ & Cell polarity & $S C^{b}$ \\
\hline GIC2 & $\begin{array}{l}\text { CRIB domain-containing Cdc42 } \\
\text { effector }\end{array}$ & Cell polarity & $\mathrm{SC}^{\mathrm{b}}$ \\
\hline BUD6 & $\begin{array}{l}\text { Actin and forming interacting } \\
\text { protein }\end{array}$ & Cell polarity & $\mathrm{SC}$ \\
\hline CDC12 & Septin subunit & Cell polarity & $\mathrm{SC}^{\mathrm{c}}$ \\
\hline RVS161 & $\begin{array}{l}\text { Amphiphysin-like protein } \\
\text { involved in actin organization } \\
\text { and membrane traffic }\end{array}$ & Cell polarity & \\
\hline MYO4 & Type V myosin & RNA Transport & \\
\hline
\end{tabular}

Process refers to process gene functions during yeast mating with emphasis on chemotropism.

Pheromone defect refers to defects in the mating process or pheromone responses of specific mutant alleles:

CS Cell shape (shmoo formation defects)

CF Cell fusion

DC Direct chemotropism assays (micropipet and microfluidics chamber-generated gradients)

IC Indirect chemotropism assays (mating partner discrimination and confusion assay)

GI Gene induction

Functions from Saccharomyces genome database (SGD: http://www.yeastgenome.org/)

References not in text:

a (Barale et al. 2006)

b(Brown et al. 1997; Jaquenoud and Peter 2000)

c(Giot and Konopka 1997)

is given a choice between two mating partners of the opposite mating type. In the competition assay, there are two types of mating partners present: target and challenger cells. Typically, the target cells are wild-type, and the genotype of the challenger cells is varied. The importance of a given challenger cell is assessed by its effect on the mating of signaling cells with the target (responder) cells. In the discrimination assay, the relative mating efficiency of one cell with two different partners is determined, measuring the ability of one cell to discriminate between two mating partners. The confusion assay examines the importance of the pheromone gradient during mating by determining the effect of disrupting the gradient by $\alpha$-factor addition (Dorer et al. 1995; Valtz et al. 1995). This results in a substantial decrease in mating efficiency with wild-type cells not observed, however, with chemotropism mutants. Although these assays are extremely useful in the identification and analysis of cellular components required for chemotropic growth, they are indirect measures of chemotropism.

The pheromone receptor, the G $\alpha, G \beta$ and Gy subunits, Sst2, and Bar1 have been shown by both the discrimination and confusion assays to be important for chemotropism 
R.A. Arkowitz

(Jackson and Hartwell 1990a; Jackson et al. 1991; Schrick et al. 1997). The discrimination assay has also revealed that actin, myosin V, and clathrin are likely to be required for chemotropism (Jackson et al. 1991). The effects of the sst 2 and bar 1 mutants in the discrimination and confusion assays is probably caused by their altered pheromone sensitivity (Jackson and Hartwell 1990a; Dorer et al. 1995). These assays have also shown that different components of the pheromone-dependent MAP kinase pathway are not required for chemotropism (Schrick et al. 1997; Strickfaden and Pryciak 2008). Interestingly, MAP kinase Fus3 mutants are somewhat defective in mating-partner discrimination (Dorer et al. 1997), whereas fus3 $\Delta$ $k s s 1 \Delta$ mutants are not. In contrast, both of these mutants are unaffected in the pheromoneconfusion assay (Dorer et al. 1997). A far1s mutant was only slightly defective in the discrimination assay, yet fully defective in the pheromone confusion assay (Dorer et al. 1995; Valtz et al. 1995).

Specific mutants for the $\alpha$-factor receptor, $\mathrm{G} \alpha$, and $\mathrm{G} \beta$ have also been examined with these assays; the former two are defective in the mating partner discrimination assay (Jackson and Hartwell 1990a; Metodiev et al. 2002), and latter is defective in the confusion assay (Strickfaden and Pryciak 2008). The defect of the Ste2 mutant lacking its cytoplasmic carboxy terminal tail (ste2-T326) in the mating partner discrimination assay is thought to be because of its increased sensitivity to pheromone (Jackson and Hartwell 1990a). The mating partner discrimination defect observed with the $g p a 1^{E E}$ mutant, together with the observation that it is defective in binding Fus3,

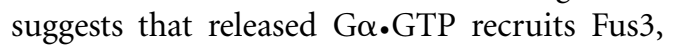
which then phosphorylates proteins required for chemotropism. The $\mathrm{G} \beta$ mutations ste4[K126E] and ste4[L117R] disrupt interactions with $\mathrm{G} \alpha$ and the pheromone receptor (Strickfaden and Pryciak 2008). Finally, both discrimination and confusion assays have been used to confirm that a range of proteins required for polarized growth and morphology changes in response to pheromone- such as Spa2, Bni1, Fus1, Fus2, Pea2, Rvs161, Bud proteins,
Myo4, and tubulin-are not necessary for chemotropism (Jackson et al. 1991; Dorer et al. 1997).

Segall developed a direct measure of chemotropism in which the direction of growth of MATa cells in a micropipet-generated gradient is followed (Segall 1993). This assay was used to show that bar1 mutants orient their growth normally toward the pheromone source, whereas sst2 mutants are somewhat defective. This assay has also revealed that bud1, spa2, $k s s 1$, afr 1, ste20 and mating defective bem1-m1 mutants all orient their growth normally in a pheromone gradient (Leberer et al. 1997; Butty et al. 2002; Vallier et al. 2002). A ste2-T326 mutant orients growth in a pheromone gradient (at lower pheromone concentrations compared with the wild type), yet is unable to increase its orientation toward the source of pheromone over time as is observed with wild-type cells (Vallier et al. 2002). Far1 ( far1-H7 and far1-D1) and $c d c 24$ (cdc24-m1 and $c d c 24-m 3$ ) mutant alleles, which are specifically defective in mating, are defective in the pheromone-confusion assay and in oriented growth toward a pheromone gradient (Valtz et al. 1995; Nern and Arkowitz 1998). Both of these types of mutants, instead, orient their mating projections adjacent to the site of their previous bud scar, i.e., mate by default.

Considered together, results suggest that two different landmarks, either that dictated by previous bud site or by pheromone gradient, activate the small G-protein Cdc42; Cdc42, in turn, is critical for directing the actin cytoskeleton and ultimately the site-specific incorporation of new plasma membrane and cell-wall material. It is presumed that limiting amounts of the $\mathrm{Cdc} 42$ activator $\mathrm{Cdc} 24$, at either site ensures that budding and shmooing can not occur simultaneously. Recently, pheromone gradients generated in a microfluidics chamber have been used to assess yeast chemotropism (Fig. 4) (Paliwal et al. 2007; Hao et al. 2008; Moore et al. 2008). The advantage of this method is that the pheromone gradient can be exquisitely controlled and its slope and concentration can be easily quantified. These studies have shown quantitatively that optimal 
chemotropism occurs at average pheromone concentrations at the receptor $\mathrm{K}_{\mathrm{d}}$ and, as expected, with steeper pheromone gradients. At low pheromone concentrations, in which barl mutant strains are able to orient their mating projections, a kss1 $1 \Delta$ barl mutant is somewhat defective. Hence, the $k s s 1 \Delta$ mutation decreases the range of pheromone concentration at which a directional response is efficient and in addition, this mutant is defective in improving its directional growth over time (Paliwal et al. 2007). Another microfluidicschamber study showed that fus $3 \triangle B A R 1$ cells and a Ste5 mutant in which Fus3 docking is defective $\left(s t e 5^{N D}\right.$ in combination with $k s s 1 \Delta$ ) were both defective in chemotropic growth, whereas kss $1 \triangle$ BAR1 mutants were unaffected (Hao et al. 2008). Together, these studies highlight the importance of the pheromonedependent MAP kinases in chemotropic growth. It is likely that the different results regarding the chemotropism of kss $1 \Delta$ strains is caused by the presence or absence of Barl, which alters the shape of the pheromone gradient.

A recent microfluidics-chamber gradient study (Moore et al. 2008) revealed that a Ste2 receptor truncation mutant, ste2 ${ }^{300 \Delta}$ (in a barls strain) was unable to orient toward a shallow gradient at high pheromone concentrations ( $\sim 90 \mathrm{nM} \alpha$-factor in a $0-100 \mathrm{nM}$ gradient), yet was able to orient toward the same gradient at lower pheromone concentrations. In a $0-1000 \mathrm{nM}$ pheromone gradient, the orientation defect of these cells is more striking. It is likely that these mutants are defective in maintaining oriented growth (Vallier et al. 2002). Together, these defects (Vallier et al. 2002; Moore et al. 2008) suggest that the receptor carboxy-terminal tail may be important for signal amplification and desensitization.

\section{Establishment of Growth Site/Polarity Axis}

As discussed previously, activation of the pheromone receptor on pheromone binding and concomitant exchange of G $\alpha$ GTP for GDP results in dissociation of $\mathrm{G} \alpha$ from $\mathrm{G} \beta \gamma$. It is likely that both released $G \alpha$ and $G \beta \gamma$ recruit proteins that
Chemical Gradients and Chemotropism in Yeast

are critical for the establishment of a growth site, leading to a new polarity axis. G $\alpha$ most likely recruits activated Fus3 (Metodiev et al. 2002), whereas G $\beta \gamma$ most likely recruits the Cdc24-Far1 complex (Butty et al. 1998; Nern and Arkowitz 1998; Nern and Arkowitz 1999). Both Fus3 (van Drogen et al. 2001; Metodiev et al. 2002; Blackwell et al. 2003; Maeder et al. 2007; Slaughter et al. 2007) and Cdc24-Far1 (Toenjes et al. 1999; Nern and Arkowitz 2000b; Shimada et al. 2000) localize to the nucleus in G1 phase cells, and are subsequently enriched at the shmoo tip on pheromone exposure. The dynamics of nuclear Fus3 are unaffected by pheromone (van Drogen et al. 2001; Maeder et al. 2007), whereas the ratio of nuclear to cytoplasmic Fus3 signal in the presence of pheromone (Blackwell et al. 2003), suggesting that export is not affected. Rather, the appearance of a cortical anchor at the incipient shmoo tip, such as $\mathrm{G} \alpha$ or $\mathrm{G} \beta \gamma-\mathrm{Ste} 5$, is likely to alter the nuclear-cytoplasmic equilibrium (Metodiev et al. 2002; Slaughter et al. 2007). Fus3 is thought to be phosphorylated on binding to G $\beta \gamma-$ Ste 5 and this activated kinase then presumably dissociates from this shmoo-tip site; shuttles into the nucleus (van Drogen et al. 2001; Blackwell et al. 2003) and is also captured at the shmoo tip via $\mathrm{G} \alpha$, resulting in a gradient of phosphorylated Fus3 (Maeder et al. 2007). With respect to the Cdc24-Far1, pheromone appears to trigger nuclear export (Blondel et al. 1999; Nern and Arkowitz 2000b; Shimada et al. 2000). Regarding the cortical recruitment of Fus3 and the Cdc24-Far1 complex, it must be kept in mind that these changes in localization have not been examined during chemotropism. Furthermore, the kinetics of the dissociation of the hetero-trimeric G-protein and of the cortical recruitment of Fus3 and Cdc24-Far1 have not been examined in these same cells, which would reveal whether dissociation of $G \alpha \beta \gamma$ is a prerequisite for recruitment.

Several studies suggest that activated phosphorylated Fus3 at the incipient shmoo tip is important for the establishment of the growth site via phosphorylation of Bnil and other substrates (Matheos et al. 2004). In addition, 
a complex of G $\beta \gamma-\mathrm{Cdc} 24-$ Far1 at the incipient shmoo tip appears to be critical for the establishment of polarity and growth orientation (Butty et al. 1998; Nern and Arkowitz 1998; Nern and Arkowitz 1999). Given that specific $\mathrm{G} \alpha$ and Fus3 alleles appear to be defective in mating partner selection (Metodiev et al. 2002; Matheos et al. 2004), it is likely that there is communication between G $\alpha$, Fus3, and Bnil proteins, on the one hand, and G $\beta \gamma$, Cdc24, and Far1 proteins on the other. Furthermore, Fus3 is required for the pheromone-dependent cortical localization of Cdc24 and Bnil (Matheos et al. 2004; Yu et al. 2008), consistent with some level of interaction between these two groups of proteins. It is, however, unclear whether G $\alpha$, Fus3, and Bnil form a stable complex or transiently associate in vivo. In vitro, G $\beta \gamma, \mathrm{Cdc} 24$, and Far1 form a complex (Nern and Arkowitz 1999), although the stability and lifetime of this complex in vivo is unknown. Furthermore, whether the communication between these two groups of proteins is direct, for example via complex formation, or indirect, e.g., by feedback loops, is unknown. One possibility is that G $\alpha$, Fus3, and Bnil are required for generating actin cables, whereas G $\beta \gamma-\mathrm{Cdc} 24-$ Far1 is involved in restricting the location of actin cables on the cell cortex. In such a scenario, it is possible that the two protein complexes activate different Rho G-proteins: For example, G $\alpha$, Fus3, and Bnil with Rho1, via interactions with Bnil (Dong et al. 2003), and G $\beta \gamma-C d c 24-$ Far1 with $\mathrm{Cdc} 42$, via Cdc24. Interestingly, G $\beta \gamma$ has also been shown to bind Rhol and recruit active Rhol to the shmoo tip (Bar et al. 2003), perhaps forming a link between these two complexes. This postulated division of labor, one generating and the other localizing actin cables, is consistent with the observation that, in $c d c 24$ and far 1, chemotropism-defective mutants, combined with bud-site selection mutants, the site of growth wanders in the presence of pheromone (Nern and Arkowitz 2000a). Particularly relevant is the wandering of the sites of secretion and the actin cytoskeleton. Nonetheless, actin cables are still visible in these mutants. It should be noted that this growth-site drift has only been examined in isotropic pheromone concentrations, and should be investigated in pheromone gradients. Naively, one would assume that chemotropismdefective $c d c 24$ or farl mutants would be unaffected by the presence of a pheromone gradient, since while they should be able to sense spatial information, they do not respond to it. It will also be critical to look at the downstream readouts of signaling via these two complexes or groups of proteins, in particular the distribution of actin cable and active Cdc42. When and where Cdc42 is activated in response to pheromone gradients remains to be determined.

\section{SIGNAL AMPLIFICATION}

As discussed, a shallow gradient of mating pheromone is sufficient for a dramatic and robust chemotropic response (Moore et al. 2008). This response can be visualized at the level of oriented growth and also at the molecular level, i.e., tight localization of a range of proteins to the tip of the mating projection. For example, after treatment with saturating isotropic concentrations or a gradient of mating pheromone, the receptors (Jackson et al. 1991; Ayscough and Drubin 1998; Stefan and Blumer 1999; Moore et al. 2008), G $\alpha$ (Metodiev et al. 2002), Gß (Kim et al. 2000), Gy (Nern and Arkowitz 2000a; Moore et al. 2008), Sst2 (Ballon et al. 2006), Fus3 (van Drogen et al. 2001; Metodiev et al. 2002; Maeder et al. 2007; Slaughter et al. 2007), Far1 (Nern and Arkowitz 2000b; Wiget et al. 2004), Cdc24 (Toenjes et al. 1999; Nern and Arkowitz 2000b; Shimada et al. 2000; Wiget et al. 2004), Bem1 (Ayscough and Drubin 1998; Butty et al. 2002), Ste20 (Peter et al. 1996; Leberer et al. 1997; Ash et al. 2003), Cdc42 (Ziman et al. 1993; Ayscough and Drubin 1998), Bnil (Evangelista et al. 1997; Matheos et al. 2004), and Spa2 (Snyder 1989; Arkowitz and Lowe 1997; Ayscough and Drubin 1998; Moore et al. 2008) are all localized to the mating projection. The receptor and the proteins that bind directly to it $(\mathrm{G} \alpha \beta \gamma$ and Sst2) are localized to the entire region of new 
growth, i.e., over the entire surface of the mating projection, whereas the rest of these proteins are localized to restricted spots at the shmoo tip (Fig. 1). The localization of all proteins examined thus far (Ste2, Ste18, Ste20, Spa2, Cdc24, and Fus3) in cells exposed to a pheromone gradient (during mating or microfluidics chamber-generated) was qualitatively similar to that observed in isotropic saturating pheromone conditions. Although a range of amplification mechanisms and feedback loops have been examined for pheromone-dependent MAP kinase signaling, little is known about the amplification mechanisms that operate during chemotropism. Furthermore, it is likely that spatial amplification mechanisms vary over time, in that initial signal amplification events are distinct from those that occur after substantial exposure to a pheromone gradient (in which cell morphology changes and hence directed secretion play a major role). It appears that the localization of the pheromone receptor and associated $\mathrm{G} \alpha \beta \gamma$ reflects the pheromone gradient. However, it remains to be seen whether the cellular distribution of activated receptor, phosphorylated receptor or hetero-trimeric G-protein, and/or dissociated hetero-trimeric G-protein also mirrors the pheromone gradient, or whether the distribution of such activated components already reveals substantial amplification.

One can imagine that endocytosis and exocytosis are critical for signal amplification during chemotropism. Indeed, Ste2 endocytosis is required for optimal mating projection reorientation (Vallier et al. 2002). Such endocytosis and exocytosis amplification mechanisms would likely depend on specific cellular locations (shmoo tip vs. opposite end of cell), pheromone exposure (magnitude and slope of gradient), and a range of posttranslational modifications. Furthermore, membrane traffic could also contribute to amplification by affecting G-proteins (hetero-trimeric and small Rho GTPases), which are presumably modified at the endoplasmic reticulum and/or Golgi complex (Michaelson et al. 2002; Wright and Philips 2006). It has been suggested that amplification occurs at the level of the formation
Chemical Gradients and Chemotropism in Yeast

of the chemotropic protein complexes, i.e., G $\alpha$-Fus3-Bni1 and G $\beta \gamma-C d c 24-F a r 1$. Amplification of spatial signals subsequent to the establishment of the initial pheromone gradient asymmetry is likely to also involve a positive feedback loop comprised of Cdc42-dependent actin polymerization and actin cable-dependent vesicle transport of Cdc42.GTP to the plasma membrane (Wedlich-Soldner et al. 2003; Wedlich-Soldner et al. 2004). Computer simulations of yeast chemotropism suggest that amplification comes from strong cooperativity and positivefeedback loops (Yi et al. 2007; Moore et al. 2008). In such a model, a Hill coefficient of $>100$ is required for polarization, and the investigators speculate that this may arise from the assembly of large protein complexes and cooperative binding reactions. The positivefeedback loop that Yi et al. modeled involves activated Cdc42 stimulating its own activation via Cdc24, Cdc42, and Bem1 (Butty et al. 2002). It is unlikely that this feedback loop plays a critical role in spatial signal amplification since a bem1-m1 mating mutant that does not bind Cdc24 and Far1 orients its growth normally in a pheromone gradient (Butty et al. 2002). One aspect of chemotropic finetuning that has been largely unexplored is the process of reorientation following a change in pheromone gradient direction. The ability to generate a range of pheromone gradients with different slopes and average concentrations will undoubtedly facilitate studies on the finetuning of directional responses.

\section{PERSPECTIVES AND OUTSTANDING QUESTIONS}

A range of cells and tissues are able to detect chemical gradients, transducing extremely shallow gradients - which result in very small differences in ligand concentration across the cell surface-into steep intracellular signaling protein gradients. These resulting intracellular gradients are essential for directional growth and movement. During mating, yeast cells generate, sense, and respond to chemical gradients by directional growth toward their mating 


\section{R.A. Arkowitz}

partner. It is likely that the ability of a cell to select the mating partner with the steepest pheromone gradient ensures the proximity of the partner and its maximal mating competence. Although a number of proteins are required for the yeast mating process, relatively few are known to have direct roles in chemotropic growth, from gradient detection to directional response. Despite the large number of studies on yeast chemotropism, many fundamental questions remain:

1. What is the contour of the pheromone gradient during the mating process?

2. What are limits of gradient detection, i.e., the shallowest and steepest gradients that cells can detect?

3. What amplification mechanisms enable the conversion of small differences in ligand concentration across the yeast cell into chemotropic growth?

4. What is the first protein required for chemotropism that is substantially amplified (localization and/or activity) relative to the pheromone gradient?

5. Is there a global inhibition mechanism during chemotropism?

6. What restricts the location or maintains the boundaries of local excitatory signals and, conversely, are inhibitory signals uniformly distributed?

7. Are membrane composition and barriers to membrane diffusion critical for chemotropic growth?

8. How do cells eliminate stochastic noise in chemical gradients and chemotropic signaling cascades?

It will be critical to address these and other questions by examining chemotropism both in a physiological context, i.e., during mating, and in conditions in which the pheromone gradient can be quantitated, such as in microfluidics chambers. The ability to carry out genetic, biochemical, and high-resolution imaging approaches in yeast makes this system ideal for elucidating the basic principles of gradient sensing and directional responses that will undoubtedly be relevant to a range of chemotropic and chemotaxic processes.

\section{ACKNOWLEDGMENTS}

I thank P. Follette and M. Bassilana for useful comments on the manuscript and in particular D. Stone for stimulating discussions. I apologize for not citing all primary work because of space limitations. R.A. is grateful for support from the Centre National de la Recherche Scientifique (CNRS), the Agence National de la Recherche (ANR), and the Fondation pour la Recherche Médicale (FRM) - BNP Paribas.

\section{REFERENCES}

Apanovitch DM, Slep KCKC, Sigler PB, Dohlman HG. 1998. Sst2 is a GTPase-activating protein for Gpa 1: Purification and characterization of a cognate RGS-Galpha protein pair in yeast. Biochemistry 37: 4815-4822.

Arkowitz RA, Lowe N. 1997. A small conserved domain in the yeast Spa2p is necessary and sufficient for its polarized localization. J Cell Biol 138: 17-36.

Arkowitz RA. 1999. Responding to attraction: Chemotaxis and chemotropism in Dictyostelium and yeast. Trends Cell Biol 9: 20-27.

Ash J, Wu C, Larocque R, Jamal M, Stevens W, Osborne M, Thomas DY, Whiteway M. 2003. Genetic analysis of the interface between Cdc42p and the CRIB domain of Ste20p in Saccharomyces cerevisiae. Genetics 163: 9-20.

Ayscough KR, Drubin DG. 1998. A role for the yeast actin cytoskeleton in pheromone receptor clustering and signalling. Curr Biol 8: 927-930.

Ballensiefen W, Schmitt HD. 1997. Periplasmic Bar1 protease of Saccharomyces cerevisiae is active before reaching its extracellular destination. Eur J Biochem 247: 142-147.

Ballon DR, Flanary PL, Gladue DP, Konopka JB, Dohlman HG, Thorner J. 2006. DEP-domain-mediated regulation of GPCR signaling responses. Cell 126: 1079-1093.

Bar EE, Ellicott AT, Stone DE. 2003. Gbetagamma recruits Rhol to the site of polarized growth during mating in budding yeast. J Biol Chem 278: 21798-21804.

Barale S, McCusker D, Arkowitz RA. 2004. The exchange factor Cdc24 is required for cell fusion during yeast mating. Eukaryot Cell 3: 1049-1061.

Barale S, McCusker D, Arkowitz RA. 2006. Cdc42p GDP/ GTP cycling is necessary for efficient cell fusion during yeast mating. Mol Biol Cell 17: 2824-2838.

Barkai N, Rose MD, Wingreen NS. 1998. Protease helps yeast find mating partners. Nature 396: 422-423.

Blackwell E, Halatek IM, Kim HJ, Ellicott AT, Obukhov AA, Stone DE. 2003. Effect of the pheromone-responsive G(alpha) and phosphatase proteins of Saccharomyces 
cerevisiae on the subcellular localization of the Fus3 mitogen-activated protein kinase. Mol Cell Biol 23: $1135-1150$.

Blondel M, Alepuz PM, Huang LS, Shaham S, Ammerer G, Peter M. 1999. Nuclear export of Farlp in response to pheromones requires the export receptor Msn5p/ Ste21p. Genes Dev 13: 2284-2300.

Blumer KJ, Thorner J. 1990. Beta and gamma subunits of a yeast guanine nucleotide-binding protein are not essential for membrane association of the alpha subunit but are required for receptor coupling. Proc Natl Acad Sci 87: 4363-4367.

Brown JL, Jaquenoud M, Gulli MP, Chant J, Peter M. 1997. Novel Cdc42-binding proteins Gic1 and Gic2 control cell polarity in yeast. Genes Dev 11: 2972-2982.

Butty AC, Perrinjaquet N, Petit A, Jaquenoud M, Segall JE, Hofmann K, Zwahlen C, Peter M. 2002. A positive feedback loop stabilizes the guanine-nucleotide exchange factor Cdc24 at sites of polarization. $E M B O J$ 21: 1565-1576.

Butty AC, Pryciak PM, Huang LS, Herskowitz I, Peter M 1998. The role of Farlp in linking the heterotrimeric $G$ protein to polarity establishment proteins during yeast mating. Science 282: 1511-1516.

Caldwell GA, Naider F, Becker JM. 1995. Fungal lipopeptide mating pheromones: A model system for the study of protein prenylation. Microbiol Rev 59: 406-422.

Caldwell GA, Wang SH, Xue CB, Jiang Y, Lu HF, Naider F, Becker JM. 1994. Molecular determinants of bioactivity of the Saccharomyces cerevisiae lipopeptide mating pheromone. J Biol Chem 269: 19817-19825.

Celic A, Martin NP, Son CD, Becker JM, Naider F, Dumont ME. 2003. Sequences in the intracellular loops of the yeast pheromone receptor Ste2p required for $G$ protein activation. Biochemistry 42: 3004-3017.

Chenevert J, Valtz N, Herskowitz I. 1994. Identification of genes required for normal pheromone-induced cell polarization in Saccharomyces cerevisiae. Genetics 136: 1287-1296.

Ciejek E, Thorner J. 1979. Recovery of S. cerevisiae a cells from G1 arrest by alpha factor pheromone requires endopeptidase action. Cell 18: 623-635.

Clark CD, Palzkill T, Botstein D. 1994. Systematic mutagenesis of the yeast mating pheromone receptor third intracellular loop. J Biol Chem 269: 8831-8841.

Cole GM, Stone DE, Reed SI. 1990. Stoichiometry of G protein subunits affects the Saccharomyces cerevisiae mating pheromone signal transduction pathway. Mol Cell Biol 10: 510-517.

Davis NG, Horecka JL, Sprague GF Jr. 1993. Cis- and transacting functions required for endocytosis of the yeast pheromone receptors. J Cell Biol 122: 53-65.

DiBello PR, Garrison TR, Apanovitch DM, Hoffman G, Shuey DJ, Mason K, Cockett MI, Dohlman HG. 1998. Selective uncoupling of RGS action by a single point mutation in the G protein alpha-subunit. J Biol Chem 273: $5780-5784$.

Dohlman HG. 2002. G proteins and pheromone signaling. Annu Rev Physiol 64: 129-152.

Dohlman HG, Goldsmith P, Spiegel AM, Thorner J. 1993. Pheromone action regulates G-protein alpha-subunit
Chemical Gradients and Chemotropism in Yeast

myristoylation in the yeast Saccharomyces cerevisiae. Proc Natl Acad Sci 90: 9688-9692.

Dohlman HG, Thorner JW. 2001. Regulation of G proteininitiated signal transduction in yeast: Paradigms and principles. Annu Rev Biochem 70: 703-754.

Dong Y, Pruyne D, Bretscher A. 2003. Formin-dependent actin assembly is regulated by distinct modes of Rho signaling in yeast. J Cell Biol 161: 1081-1092.

Dorer R, Boone C, Kimbrough T, Kim J, Hartwell LH. 1997. Genetic analysis of default mating behavior in Saccharomyces cerevisiae. Genetics 146: 39-55.

Dorer R, Pryciak PM, Hartwell LH. 1995. Saccharomyces cerevisiae cells execute a default pathway to select a mate in the absence of pheromone gradients. J Cell Biol 131: 845-861.

Dosil M, Schandel KA, Gupta E, Jenness DD, Konopka JB. 2000. The $\mathrm{C}$ terminus of the Saccharomyces cerevisiae alpha-factor receptor contributes to the formation of preactivation complexes with its cognate $\mathrm{G}$ protein. Mol Cell Biol 20: 5321-5329.

Dube P, DeCostanzo A, Konopka JB. 2000. Interaction between transmembrane domains five and six of the alpha -factor receptor. J Biol Chem 275: 26492-26499.

Erdman S, Lin L, Malczynski M, Snyder M. 1998. Pheromone-regulated genes required for yeast mating differentiation. J Cell Biol 140: 461-483.

Evangelista M, Blundell K, Longtine MS, Chow CJ, Adames N, Pringle JR, Peter M, Boone C. 1997. Bnilp, a yeast formin linking cdc42p and the actin cytoskeleton during polarized morphogenesis. Science 276: 118-122.

Giot L, Konopka JB. 1997. Functional analysis of the interaction between Afrlp and the Cdc12p septin, two proteins involved in pheromone-induced morphogenesis. Mol Biol Cell 8: 987-998.

Goodhill GJ. 1998. Mathematical guidance for axons. Trends Neurosci 21: 226-231.

Goodhill GJ, Baier H. 1998. Axon guidance: Stretching gradients to the limit. Neural Comput 10: 521-527.

Grishin AV, Weiner JL, Blumer KJ. 1994. Biochemical and genetic analysis of dominant-negative mutations affecting a yeast G-protein gamma subunit. Mol Cell Biol 14: 4571-4578.

Hagen DC, Sprague GF Jr. 1984. Induction of the yeast alpha-specific STE3 gene by the peptide pheromone a-factor. J Mol Biol 178: 835-852.

Hao N, Nayak S, Behar M, Shanks RH, Nagiec MJ, Errede B, Hasty J, Elston TC, Dohlman HG. 2008. Regulation of cell signaling dynamics by the protein kinase-scaffold Ste5. Mol Cell 30: 649-656.

Hartig A, Holly J, Saari G, MacKay VL. 1986. Multiple regulation of STE2, a mating-type-specific gene of Saccharomyces cerevisiae. Mol Cell Biol 6: 2106-2114.

Hauser M, Kauffman S, Lee BK, Naider F, Becker JM. 2007. The first extracellular loop of the Saccharomyces cerevisiae $\mathrm{G}$ protein-coupled receptor Ste2p undergoes a conformational change upon ligand binding. J Biol Chem 282: 10387-10397.

Hirsch JP, Dietzel C, Kurjan J. 1991. The carboxyl terminus of Scg1, the G alpha subunit involved in yeast mating, is implicated in interactions with the pheromone receptors. Genes Dev 5: 467-474. 


\section{R.A. Arkowitz}

Hirschman JE, De Zutter GS, Simonds WF, Jenness DD. 1997. The $\mathrm{G}$ beta gamma complex of the yeast pheromone response pathway. Subcellular fractionation and protein-protein interactions. J Biol Chem 272: 240-248.

Hirschman JE, Jenness DD. 1999. Dual lipid modification of the yeast Ggamma subunit Ste18p determines membrane localization of Gbetagamma. Mol Cell Biol 19: 7705-7711.

Isbister CM, Mackenzie PJ, To KC, O’Connor TP. 2003. Gradient steepness influences the pathfinding decisions of neuronal growth cones in vivo. J Neurosci 23: 193-202.

Jackson CL, Hartwell LH. 1990a. Courtship in S. cerevisiae: Both cell types choose mating partners by responding to the strongest pheromone signal. Cell 63: 1039-1051.

Jackson CL, Hartwell LH. 1990b. Courtship in Saccharomyces cerevisiae: An early cell-cell interaction during mating. Mol Cell Biol 10: 2202-2213.

Jackson CL, Konopka JB, Hartwell LH. 1991. S. cerevisiae alpha pheromone receptors activate a novel signal transduction pathway for mating partner discrimination. Cell 67: 389-402.

Jahng KY, Ferguson J, Reed SI. 1988. Mutations in a gene encoding the alpha subunit of a Saccharomyces cerevisiae $G$ protein indicate a role in mating pheromone signaling. Mol Cell Biol 8: 2484-2493.

Janetopoulos C, Ma L, Devreotes PN, Iglesias PA. 2004. Chemoattractant-induced phosphatidylinositol 3,4,5trisphosphate accumulation is spatially amplified and adapts, independent of the actin cytoskeleton. Proc Natl Acad Sci 101: 8951-8956.

Jaquenoud M, Peter M. 2000. Gic2p may link activated Cdc42p to components involved in actin polarization, including Bnilp and Bud6p (Aip3p). Mol Cell Biol 20: 6244-6258.

Jenness DD, Burkholder AC, Hartwell LH. 1986. Binding of alpha-factor pheromone to Saccharomyces cerevisiae a cells: Dissociation constant and number of binding sites. Mol Cell Biol 6: 318-320.

Jenness DD, Spatrick P. 1986. Down regulation of the alpha-factor pheromone receptor in S. cerevisiae. Cell 46: $345-353$.

Khouri O, Sherrill C, Roise D. 1996. Partitioning of a-factor analogues into membranes: Analysis of binding and importance for biological activity. Biochemistry 35: 14553-14560.

Kim J, Bortz E, Zhong H, Leeuw T, Leberer E, Vershon AK, Hirsch JP. 2000. Localization and signaling of G(beta) subunit Ste4p are controlled by a-factor receptor and the a-specific protein Asg7p. Mol Cell Biol 20: 8826-8835.

Konopka JB, Jenness DD. 1991. Genetic fine-structural analysis of the Saccharomyces cerevisiae alpha-pheromone receptor. Cell Regul 2: 439-452.

Konopka JB, Jenness DD, Hartwell LH. 1988. The C-terminus of the S. cerevisiae alpha-pheromone receptor mediates an adaptive response to pheromone. Cell 54: 609-620.

Kuchler K, Dohlman HG, Thorner J. 1993. The a-factor transporter (STE6 gene product) and cell polarity in the yeast Saccharomyces cerevisiae. J Cell Biol 120: 1203-1215.
Leberer E, Wu C, Leeuw T, Fourest-Lieuvin A, Segall JE, Thomas DY. 1997. Functional characterization of the $\mathrm{Cdc} 42 \mathrm{p}$ binding domain of yeast Ste20p protein kinase. EMBO J 16: 83-97.

Lin JC, Parrish W, Eilers M, Smith SO, Konopka JB. 2003. Aromatic residues at the extracellular ends of transmembrane domains 5 and 6 promote ligand activation of the $\mathrm{G}$ protein-coupled alpha-factor receptor. Biochemistry 42: $293-301$.

Madden K, Snyder M. 1992. Specification of sites for polarized growth in Saccharomyces cerevisiae and the influence of external factors on site selection. Mol Biol Cell 3: 1025-1035.

Maeder CI, Hink MA, Kinkhabwala A, Mayr R, Bastiaens PI, Knop M. 2007. Spatial regulation of Fus3 MAP kinase activity through a reaction-diffusion mechanism in yeast pheromone signalling. Nat Cell Biol 9: 1319-1326.

Manahan CL, Patnana M, Blumer KJ, Linder ME. 2000 Dual lipid modification motifs in G(alpha) and $\mathrm{G}$ (gamma) subunits are required for full activity of the pheromone response pathway in Saccharomyces cerevisiae. Mol Biol Cell 11: 957-968.

Marcus S, Xue CB, Naider F, Becker JM. 1991. Degradation of a-factor by a Saccharomyces cerevisiae alphamating-type-specific endopeptidase: Evidence for a role in recovery of cells from G1 arrest. Mol Cell Biol 11: 1030-1039.

Matheos D, Metodiev M, Muller E, Stone D, Rose MD. 2004. Pheromone-induced polarization is dependent on the Fus3p MAPK acting through the formin Bnilp. J Cell Biol 165: 99-109.

Metodiev MV, Matheos D, Rose MD, Stone DE. 2002. Regulation of MAPK function by direct interaction with the mating-specific Galpha in yeast. Science 296: 1483-1486.

Michaelson D, Ahearn I, Bergo M, Young S, Philips M. 2002. Membrane trafficking of heterotrimeric G proteins via the endoplasmic reticulum and Golgi. Mol Biol Cell 13: 3294-3302.

Moore TI, Chou CS, Nie Q, Jeon NL, Yi TM. 2008. Robust spatial sensing of mating pheromone gradients by yeast cells. PLoS ONE 3: pe3865.

Moukadiri I, Jaafar L, Zueco J. 1999. Identification of two mannoproteins released from cell walls of a Saccharomyces cerevisiae mnn 1 mnn 9 double mutant by reducing agents. J Bacteriol 181: 4741-4745.

Nern A, Arkowitz RA. 1998. A GTP-exchange factor required for cell orientation. Nature 391: 195-198.

Nern A, Arkowitz RA. 1999. A Cdc24p-Farlp-Gbetagamma protein complex required for yeast orientation during mating. J Cell Biol 144: 1187-1202.

Nern A, Arkowitz RA. 2000a. G proteins mediate changes in cell shape by stabilizing the axis of polarity. Mol Cell 5: 853-864.

Nern A, Arkowitz RA. 2000b. Nucleocytoplasmic shuttling of the Cdc42p exchange factor Cdc24p. J Cell Biol 148: 1115-1122.

Nomoto S, Nakayama N, Arai K, Matsumoto K. 1990. Regulation of the yeast pheromone response pathway by G protein subunits. EMBO J 9: 691-696. 
Overton MC, Blumer KJ. 2000. G-protein-coupled receptors function as oligomers in vivo. Curr Biol 10:341-344.

Paliwal S, Iglesias PA, Campbell K, Hilioti Z, Groisman A, Levchenko A. 2007. MAPK-mediated bimodal gene expression and adaptive gradient sensing in yeast. Nature 446: 46-51.

Peter M, Neiman AM, Park HO, van Lohuizen M, Herskowitz I. 1996. Functional analysis of the interaction between the small GTP binding protein Cdc42 and the Ste 20 protein kinase in yeast. $E M B O J$ 15: 7046-7059.

Schandel KA, Jenness DD. 1994. Direct evidence for ligand-induced internalization of the yeast alpha-factor pheromone receptor. Mol Cell Biol 14: 7245-7255.

Schrick K, Garvik B, Hartwell LH. 1997. Mating in Saccharomyces cerevisiae: The role of the pheromone signal transduction pathway in the chemotropic response to pheromone. Genetics 147: 19-32.

Segall JE. 1993. Polarization of yeast cells in spatial gradients of alpha mating factor. Proc Natl Acad Sci 90: 8332-8336.

Shimada Y, Gulli MP, Peter M. 2000. Nuclear sequestration of the exchange factor $\mathrm{Cdc} 24$ by Far1 regulates cell polarity during yeast mating. Nat Cell Biol 2: 117-124.

Slaughter BD, Schwartz JW, Li R. 2007. Mapping dynamic protein interactions in MAP kinase signaling using livecell fluorescence fluctuation spectroscopy and imaging. Proc Natl Acad Sci 104: 20320-20325.

Slessareva JE, Routt SM, Temple B, Bankaitis VA, Dohlman HG. 2006. Activation of the phosphatidylinositol 3-kinase Vps34 by a $\mathrm{G}$ protein alpha subunit at the endosome. Cell 126: 191-203.

Snyder M. 1989. The SPA2 protein of yeast localizes to sites of cell growth. J Cell Biol 108: 1419-1429.

Son CD, Sargsyan H, Naider F, Becker JM. 2004. Identification of ligand binding regions of the Saccharomyces cerevisiae alpha-factor pheromone receptor by photoaffinity cross-linking. Biochemistry 43: 13193-13203.

Song J, Dohlman HG. 1996. Partial constitutive activation of pheromone responses by a palmitoylation-site mutant of a $G$ protein alpha subunit in yeast. Biochemistry 35: 14806-14817.

Song J, Hirschman J, Gunn K, Dohlman HG. 1996. Regulation of membrane and subunit interactions by $\mathrm{N}$-myristoylation of a $\mathrm{G}$ protein alpha subunit in yeast. J Biol Chem 271: 20273-20283.

Stefan CJ, Blumer KJ. 1994. The third cytoplasmic loop of a yeast G-protein-coupled receptor controls pathway activation, ligand discrimination, and receptor internalization. Mol Cell Biol 14: 3339-3349.

Stefan CJ, Blumer KJ. 1999. A syntaxin homolog encoded by VAM3 mediates down-regulation of a yeast G proteincoupled receptor. J Biol Chem 274: 1835-1841.

Stefan CJ, Overton MC, Blumer KJ. 1998. Mechanisms governing the activation and trafficking of yeast $\mathrm{G}$ proteincoupled receptors. Mol Biol Cell 9: 885-899.

Stone DE, Cole GM, de Barros Lopes M, Goebl M, Reed SI 1991. N-myristoylation is required for function of the pheromone-responsive $G$ alpha protein of yeast: Conditional activation of the pheromone response by a temperature-sensitive N-myristoyl transferase. Genes Dev 5: 1969-1981.

Strickfaden SC, Pryciak PM. 2008. Distinct roles for two Galpha-Gbeta interfaces in cell polarity control by a yeast heterotrimeric G protein. Mol Biol Cell 19: 181-197.

Toenjes KA, Sawyer MM, Johnson DI. 1999. The guanine-nucleotide-exchange factor Cdc24p is targeted to the nucleus and polarized growth sites. Curr Biol 9: $1183-1186$.

Vallier LG, Segall JE, Snyder M. 2002. The alpha-factor receptor C-terminus is important for mating projection formation and orientation in Saccharomyces cerevisiae. Cell Motil Cytoskeleton 53: 251-266.

Valtz N, Herskowitz I. 1996. Pea2 protein of yeast is localized to sites of polarized growth and is required for efficient mating and bipolar budding. J Cell Biol 135: 725-739.

Valtz N, Peter M, Herskowitz I. 1995. FAR1 is required for oriented polarization of yeast cells in response to mating pheromones. J Cell Biol 131: 863-873.

van Drogen F, Stucke VM, Jorritsma G, Peter M. 2001. MAP kinase dynamics in response to pheromones in budding yeast. Nat Cell Biol 3: 1051-1059.

Walter J, Allsopp TE, Bonhoeffer F. 1990. A common denominator of growth cone guidance and collapse? Trends Neurosci 13: 447-452.

Wedlich-Soldner R, Altschuler S, Wu L, Li R. 2003. Spontaneous cell polarization through actomyosin-based delivery of the Cdc42 GTPase. Science 299: 1231-1235.

Wedlich-Soldner R, Wai SC, Schmidt T, Li R. 2004. Robust cell polarity is a dynamic state established by coupling transport and GTPase signaling. J Cell Biol 166: 889-900.

Whiteway M, Hougan L, Dignard D, Thomas DY, Bell L, Saari GC, Grant FJ, O'Hara P, MacKay VL. 1989. The STE4 and STE18 genes of yeast encode potential beta and gamma subunits of the mating factor receptorcoupled G protein. Cell 56: 467-477.

Whiteway MS, Thomas DY. 1994. Site-directed mutations altering the CAAX box of Ste18, the yeast pheromone-response pathway G gamma subunit. Genetics 137: 967-976.

Wiget P, Shimada Y, Butty AC, Bi E, Peter M. 2004. Site-specific regulation of the GEF Cdc24p by the scaffold protein Farlp during yeast mating. EMBO $J$ 23: 1063-1074.

Wright LP, Philips MR. 2006. Thematic review series: Lipid posttranslational modifications. CAAX modification and membrane targeting of Ras. J Lipid Res 47: 883-891.

Wu YL, Hooks SB, Harden TK, Dohlman HG. 2004. Dominant-negative inhibition of pheromone receptor signaling by a single point mutation in the $\mathrm{G}$ protein alpha subunit. J Biol Chem 279: 35287-35297.

Xue C, Hsueh YP, Heitman J. 2008. Magnificent seven: Roles of $\mathrm{G}$ protein-coupled receptors in extracellular sensing in fungi. FEMS Microbiol Rev 32: 1010-1032.

Yesilaltay A, Jenness DD. 2000. Homo-oligomeric complexes of the yeast alpha-factor pheromone receptor are functional units of endocytosis. Mol Biol Cell 11: 2873-2884. 


\section{R.A. Arkowitz}

Yi T-M, Chen S, Chou CS, Nie Q. 2007. Modeling Yeast Cell Polarization Induced by Pheromone Gradients J Statist Phys 128: 193-207.

Yu L, Qi M, Sheff MA, Elion EA. 2008. Counteractive control of polarized morphogenesis during mating by mitogenactivated protein kinase Fus3 and G1 cyclin-dependent kinase. Mol Biol Cell 19: 1739-1752.
Zigmond SH. 1977. Ability of polymorphonuclear leukocytes to orient in gradients of chemotactic factors. J Cell Biol 75: 606-616.

Ziman M, Preuss D, Mulholland J, O'Brien JM, Botstein D, Johnson DI. 1993. Subcellular localization of Cdc42p, a Saccharomyces cerevisiae GTP-binding protein involved in the control of cell polarity. Mol Biol Cell 4: 1307-1316. 


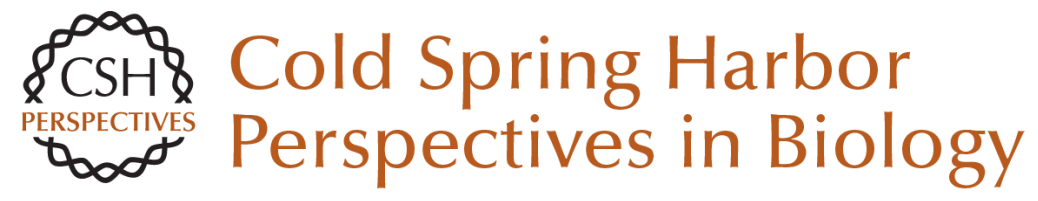

\section{Chemical Gradients and Chemotropism in Yeast}

Robert A. Arkowitz

Cold Spring Harb Perspect Biol 2009; doi: 10.1101/cshperspect.a001958 originally published online July 29, 2009

\section{Subject Collection Generation and Interpretation of Morphogen Gradients}

Regulation of Organ Growth by Morphogen Gradients

Gerald Schwank and Konrad Basler

Signaling Gradients during Paraxial Mesoderm

Development Alexander Aulehla and Olivier Pourquié

Morphogen Gradient Formation

Ortrud Wartlick, Anna Kicheva and Marcos

González-Gaitán

Nodal Morphogens

Alexander F. Schier

Gradients and the Specification of Planar Polarity

in the Insect Cuticle

David Strutt

Vertebrate Limb Development: Moving from

Classical Morphogen Gradients to an Integrated

4-Dimensional Patterning System Jean-Denis Bénazet and Rolf Zeller

Establishing and Interpreting Graded Sonic

Hedgehog Signaling during Vertebrate Neural

Tube Patterning: The Role of Negative Feedback Vanessa Ribes and James Briscoe

Systems Biology of the Self-regulating

Morphogenetic Gradient of the Xenopus Gastrula Jean-Louis Plouhinec and E. M. De Robertis
Gradients in Planarian Regeneration and Homeostasis

Teresa Adell, Francesc Cebrià and Emili Saló

Shaping Morphogen Gradients by Proteoglycans Dong Yan and Xinhua Lin

Forming Patterns in Development without Morphogen Gradients: Scattered Differentiation and Sorting Out

Robert R. Kay and Christopher R.L. Thompson

Robust Generation and Decoding of Morphogen Gradients

Naama Barkai and Ben-Zion Shilo

Models for the Generation and Interpretation of

Gradients

Hans Meinhardt

Graded Dorsal and Differential Gene Regulation in the Drosophila Embryo

Gregory T. Reeves and Angelike Stathopoulos

Chemical Gradients and Chemotropism in Yeast Robert A. Arkowitz

Gradients in the Brain: The Control of the Development of Form and Function in the Cerebral Cortex

Stephen N. Sansom and Frederick J. Livesey

For additional articles in this collection, see http://cshperspectives.cshlp.org/cgi/collection/

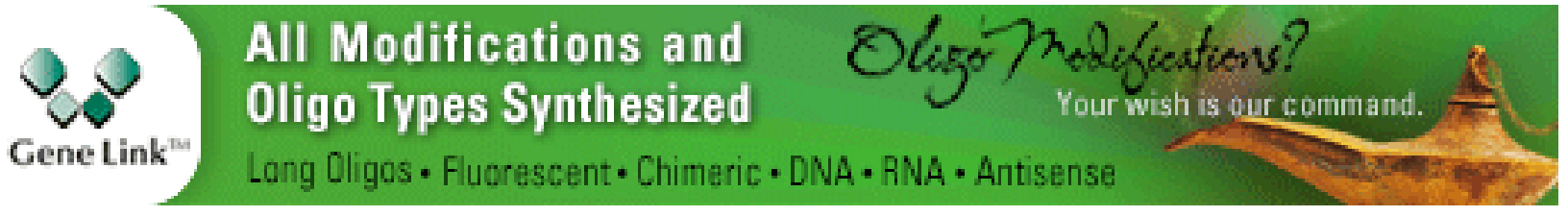


For additional articles in this collection, see http://cshperspectives.cshlp.org/cgi/collection/

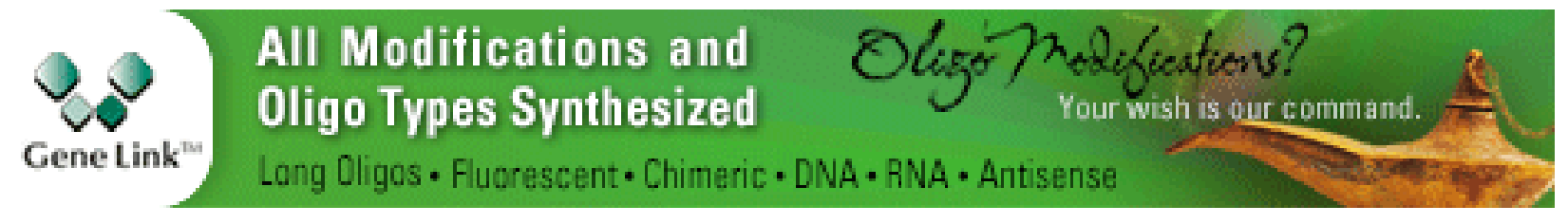

Copyright @ 2009 Cold Spring Harbor Laboratory Press; all rights reserved 